\title{
Mobiltelefoner skal slås av
}

\section{Bruk av mobiltelefon på sykehus og legekontorer virker forstyrrende, kan være en hygienisk risiko} og innebærer flere etiske og juridiske problemer.

Rådet for legeetikk er blitt spurt av Rådet for sykepleieetikk om hvordan rådet ser på bruk av mobiltelefon i arbeidssituasjoner, særlig i forhold til å ta bilder av medisinske tilstander. Bakgrunnen for forespørselen er at Rådet for sykepleieetikk har fått en henvendelse om det er tillatelig at sykepleiestudenter tar bilder av sår, brudd og liknende på privat mobiltelefon.

Rådet for legeetikk oppfordrer arbeidsgivere til å utarbeide retningslinjer for bruk av mobiltelefon på arbeidsstedet. Helsepersonell og studenter bør ikke bære mobiltelefon under arbeidet, men oppbevare den på egnet sted og begrense eventuell bruk til pauser.

For en del av helsepersonellet kan det være viktig å være tilgjengelig på mobiltelefon, men under direkte pasientkontakt bør telefonen være avslått. Om nødvendig bør vedkommende i slike situasjoner sørge for at beskjeder mottas av andre.

Bilder av medisinske tilstander, for eksempel utslett og sår, kan være viktig medisinsk dokumentasjon, som da oppbevares i pasientens journal, og til bruk i undervisningen. Arbeidsgiver bør utarbeide retningslinjer for hvem, og under hvilke forutsetninger, slike bilder kan tas, for eksempel i forhold til krav til samtykke og oppbevaring. Studenter bør ikke ha anledning til å ta bilder med mindre det er gitt et konkret unntak fra leder ved institusjonen.

Rådet for legeetikk mener at det uansett er uakseptabelt å ta bilder med privat mobiltelefon, selv om en pasient gir samtykke og bildet ikke uten videre kan knyttes til en pasient. Et bilde på mobiltelefon kan lett distribueres vidt, også utilsiktet ved et uhell. Det er derfor ikke mulig å garantere at et

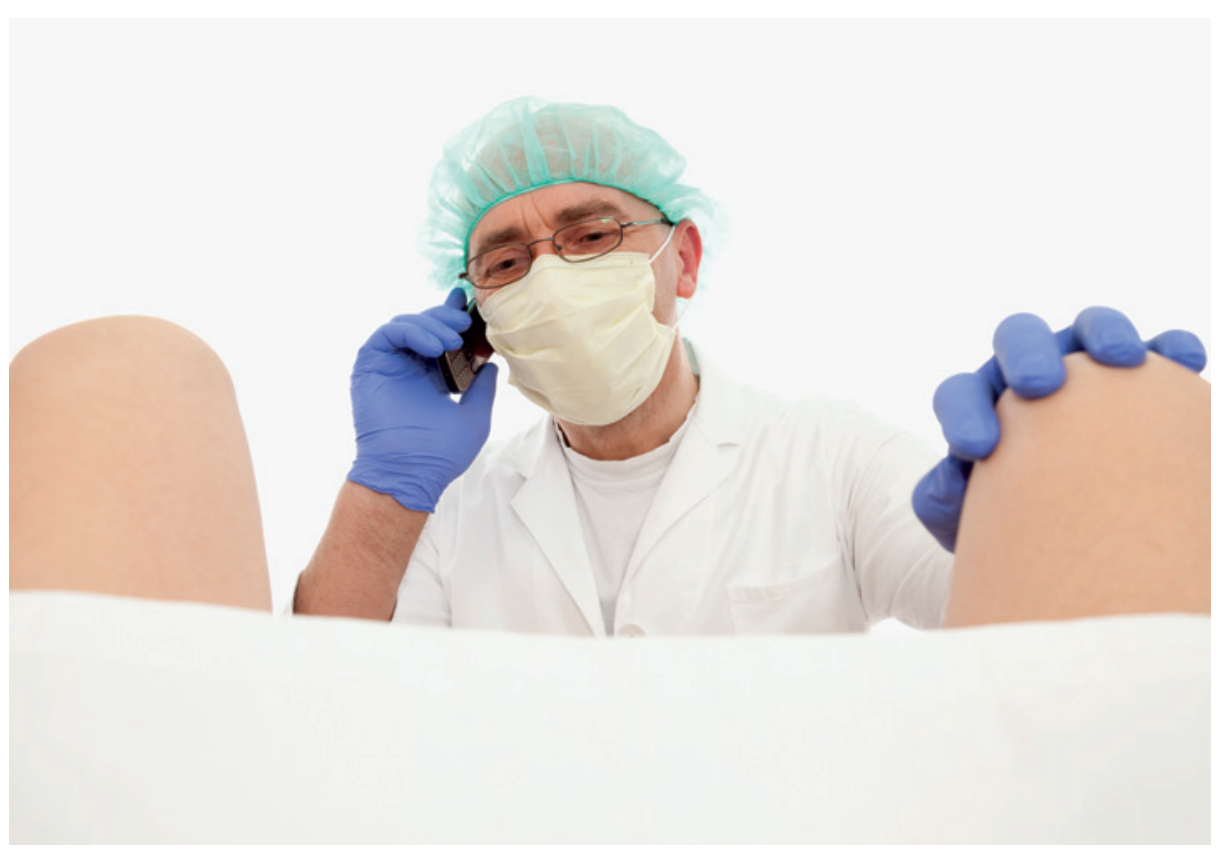

Foto Istockphoto/Thinkstock

bilde ikke vil komme til å bli knyttet direkte eller indirekte til en pasient.

Asymmetrien i en pasient-behandlerrelasjon gjør at det kan være tvil om et avgitt samtykke reelt sett er fritt. Man må derfor alltid utvise stor grad av varsomhet og takt når man ber om samtykke. Denne underliggende asymmetrien og utryggheten, opplevd eller reell, knyttet til lagring, bruk og distribusjon av bilder på mobiltelefon, bidrar til at Rådet for legeetikk ser det som uakseptabelt å spørre pasienter om å få ta bilder, selv om det er usannsynlig at bildet kan knyttes til pasienten.
Trond J. Markestad

trond.markestad@helse-bergen.no

Rådet for legeetikk

Den norske legeforening

Trond J. Markestad (f. 1945) er professor i pediatri ved Universitetet i Bergen og leder i Rådet for legeetikk i Den norske legeforening Forfatter har fylt ut ICMJE-skjemaet og oppgir ingen interessekonflikter.

Mottatt 23.2. 2012 og godkjent 8.3. 2012. Medisinsk redaktør Petter Gjersvik.

\section{Saker behandlet av Rådet for legeetikk publiseres i årsmeldingene på nettsiden www.legeforeningen.no/etikk}

